\title{
Nitrogen uptake by size-fractionated phytoplankton populations in the southern Benguela upwelling system
}

\author{
T. A. Probyn \\ Marine Biology Research Institute, University of Cape Town, Rondebosch 7700, Cape Town, South Africa
}

\begin{abstract}
Uptake of ${ }^{15} \mathrm{~N}$-labelled ammonium, nitrate and urea by picoplankton $(<1 \mu \mathrm{m})$, nanoplankton $(<10 \mu \mathrm{m})$ and the whole phytoplankton community was investigated in oceanic, shelf and inshore waters in the southern Benguela upwelling system during December 1983. Picoplankton and nanoplankton chlorophyll $a$ accounted for 2 to $49 \%$ and 13 to $99 \%$ respectively, of the whole community chlorophyll a. Picoplankton were relatively more active in oceanic as opposed to coastal waters. Nitrogen uptake by picoplankton was $27 \%$ of that by the intact phytoplankton community in oceanic waters compared to ca $10 \%$ for the coastal regions. Similarly, turnover rates of particulate nitrogen in the $<1 \mu \mathrm{m}$ size class were faster in oceanic than shelf or inshore waters. Relative preference indices showed a consistent preference for ammonium, to a lesser extent for urea, compared to nitrate by all 3 size classes. Nevertheless, nitrate was quantitatively the most important nitrogen source for the nutrition of the intact community over the shelf, supplying $71 \%$ of the total nitrogen assimilated. The proportion of nitrate assimilated was directly related to algal size class at the shelf and inshore stations with picoplankton and nanoplankton production being based largely on regenerated nitrogen (ammonium and urea). In oceanic waters, production in all size classes was supported principally be regenerated nitrogen. Results are discussed with reference to the effect of qualitative and quantitative aspects of nitrogen availability on phytoplankton community structure.
\end{abstract}

\section{INTRODUCTION}

Rate measurements on size-fractionated natural phytoplankton assemblages have emphasized carbon fixation by the netplankton and nanoplankton size categories (reviewed by Malone 1980), with relatively few studies that address aspects of nitrogen assimilation by these size classes. Results of the few studies that have been attempted do not agree about the relationship between algal size and qualitative differences in nitrogen utilization. Netplankton blooms often develop in response to a large input of nitrate into the euphotic zone through upwelling (Malone 1980). The highest specific ammonium uptake rates by phytoplankton in Vineyard Sound have been shown to be almost exclusively in the nanoplankton $(<10 \mu \mathrm{m})$ size class (Glibert at al. 1982a). Seasonal shifts were evident so that during a winter diatom bloom period 30 to $90 \%$ of ammonium uptake was due to netplankton $(<35 \mu \mathrm{m})$ activity (Glibert et al. 1982a). Nitrate uptake was not measured in this study. In contrast, Furnas
(1983) in his seasonal study in the nearby Narragansett Bay has shown that the whole phytoplankton community and nanoplankton assemblages utilize different nitrogen resources in a similar manner throughout the year with ammonium generally being quantitatively more important than either nitrate or urea. Other studies have been carried out on urea utilization and remineralization by size-fractionated plankton populations (Herbland 1976, Savidge \& Hutley 1977); these experiments employed ${ }^{14} \mathrm{C}$ labelled urea as a tracer and consequently do not indicate the fate of ureanitrogen.

Evidence is accumulating to suggest that bacterialsized organisms play an important photo-autotrophic role in the pelagic environment. The ubiquitous and usually abundant presence of both cyanobacteria (Johnson \& Sieburth 1979, Li et al. 1983) and eucaryotic algae (Johnson \& Sieburth 1982) in this size class has been demonstrated in offshore and inshore waters. Organisms in this size range $(<1 \mu \mathrm{m})$ contribute between 20 and $80 \%$ of the total primary production 
(Gieskes et al. 1979, Joint \& Pomroy 1983, Li et al. 1983). At present the nitrogen nutrition of natural assemblages of these important photo-autotrophs is poorly understood.

Detailed analyses of rate processes in natural populations of phytoplankton at sub-community levels of organization can provide valuable insight into the structure and functioning of the pelagic food web as well as the development and decay of phytoplankton blooms. The purpose of this study is to investigate the utilization of nitrogenous nutrients by broad size categories in the phytoplankton community of oceanic, continental shelf and close inshore waters, in the southern Benguela upwelling system. This study was undertaken to assess the spatial variation in nitrogen assimilation for this region and does not encompass any seasonal or shorter time scale variability.

\section{METHODS}

Sampling. Nitrogen uptake experiments were performed during December 1983 aboard RV 'Africana' off the west coast of South Africa. Stations were located over the 1000 m depth contour, the continental shelf, as

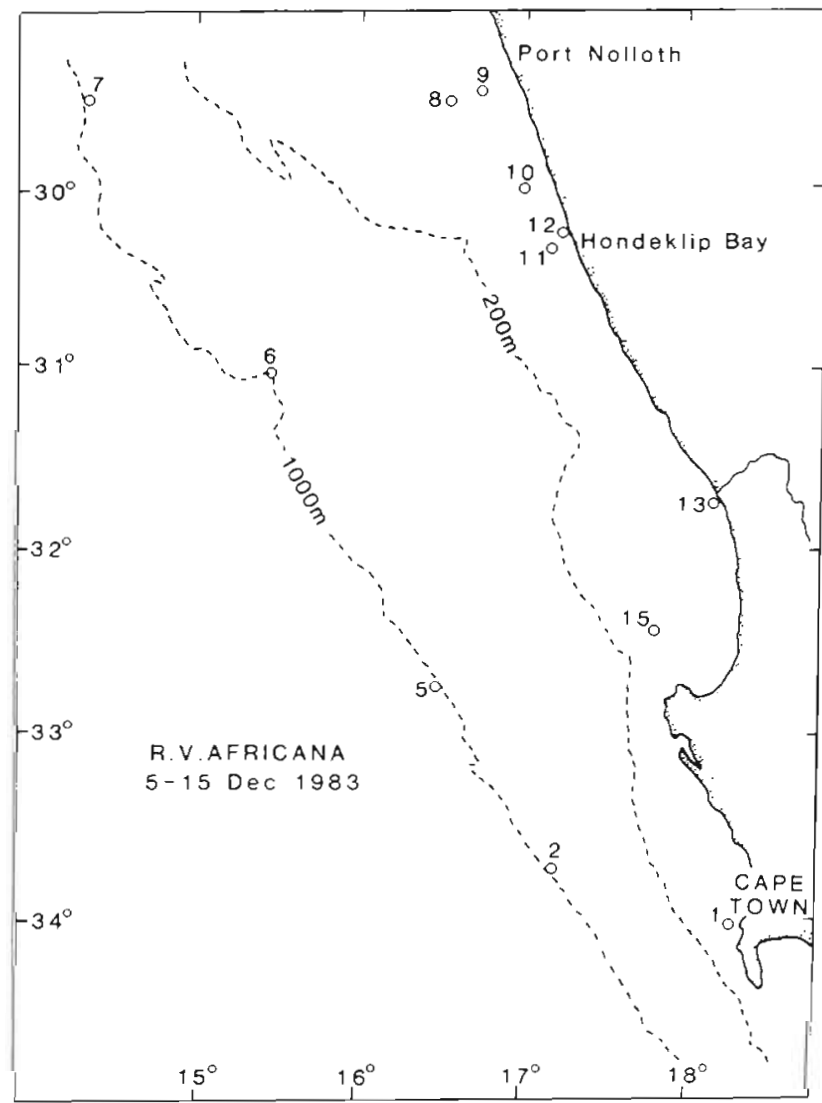

Fig. 1. Sampling area showing station numbers and 200 and $1000 \mathrm{~m}$ isobaths delineated by the $200 \mathrm{~m}$ depth contour, and close inshore (Fig. 1). Surface water was sampled in the morning using a rosette sampler or plastic bucket and combined in a $30 \mathrm{l}$ polyethylene carboy. Exactly $2 \mathrm{l}$ of water was prescreened through either a $212 \mu \mathrm{m}$ or $10 \mu \mathrm{m}$ nylon mesh into glass incubation bottles. The $<1 \mu$ m fraction, the picoplankton (Sieburth et al. 1978) was obtained by gentle vacuum filtration through $1 \mu \mathrm{m}$ Nuclepore filters. The $<10 \mu \mathrm{m}$ fraction, (nanoplankton including picoplankton) will be termed the nanoplankton fraction unless otherwise stated, to enable comparison with other studies which have not differentiated between these size classes. The $<212 \mu \mathrm{m}$ fraction is assumed to be representative of the intact phytoplankton community.

Analyses. Dissolved inorganic nitrogen concentrations were determined manually immediately after sampling and isotope addition. Nitrate was measured following the cadmium reduction method of Nydahl (1976) and ammonium according to Grasshoff (1976) scaled down to $5 \mathrm{ml}$ samples. Samples for urea determinations were frozen immediately and analysed in the laboratory according to the diacetyl monoxime procedure (Grasshoff 1976).

Particulate matter was collected on glass fibre filters (Whatman GF/F) and frozen for subsequent chlorophyll a (Jeffrey \& Humphrey 1975) corrected for phaeopigments (Strickland \& Parsons 1972), and for particulate organic carbon and nitrogen (Heraeus CHN Rapid).

Bacterial and phytoplankton counts. Samples for counting were preserved with $1 \%$ Lugol's iodine. Microbial populations were counted by epifluorescence microscopy, using acridine orange (Hobbie et al. 1977). Iodine was removed by addition of dilute sodium thiosulphate immediately prior to counting (Joint \& Pomroy 1983). Bacterial biomass was calculated from the cell volumes using a specific gravity of $1.1 \mathrm{~g} \mathrm{~cm}^{-3}$ (Doetsch \& Cook 1973) and the generally used ratio of carbon/wet biomass of 0.1 (Troitsky \& Sorokin 1967). Phytoplankton (excluding the picoplankton) were counted using an inverted microscope. No distinction was made between autotrophic and heterotrophic forms in the nanoflagellate counts.

Nitrogen uptake measurements. Nitrogen uptake rates were determined according to Dugdale \& Goering (1967). This method under-estimates ammonium and possibly urea uptake under conditions of active regeneration within the incubation bottle (Glibert et al. 1982b, Laws 1984). To $2 \mathrm{l}$ of prescreened surface water were added either $\mathrm{Na}^{15} \mathrm{NO}_{3}\left(99.6\right.$ at \%), ${ }^{15} \mathrm{NH}_{4} \mathrm{Cl}$ $\left(99.7\right.$ at \%) or $\mathrm{CO}\left({ }^{15} \mathrm{NH}_{2}\right)_{2}(99.1$ at \%) and the samples incubated for 4 to $6 \mathrm{~h}$ in unshaded simulated in situ deck boxes cooled by flowing surface seawater. Longterm incubations can be criticized on the basis of the 
often observed non-linear nutrient uptake in laboratory and field experiments (Goldman et al. 1981). The high ambient nutrient concentrations encountered at most stations during this study, however, would reduce the possibility of a transient enhancement in uptake due to isotope addition or a reduction in uptake as a result of nutrient depletion. The quantity of ${ }^{15} \mathrm{~N}$ isotope added depended on the initial nutrient concentration when prior analysis had been performed and amounted to 0.05 to $0.10 \mathrm{mg}$-at ammonium- ${ }^{15} \mathrm{~N} \mathrm{~m}^{-3}$, 0.10 to $0.20 \mathrm{mg}$-at urea- ${ }^{15} \mathrm{~N} \mathrm{~m}^{-3}$, and 0.10 to $2.50 \mathrm{mg}$-at nitrate- ${ }^{15} \mathrm{~N} \mathrm{~m}^{-3}$. Enrichments at Stations 5 and 15 were $100 \%$ for urea. Higher than trace additions were also made for urea at Station 8, ammonium at Station 10, and nitrate at Station 6 .

Uptake experiments were terminated by filtration of the particulate matter onto glass-fibre filters (Whatman $\mathrm{GF} / \mathrm{F}$ ). Filters were stored frozen and analysed for ${ }^{15} \mathrm{~N}$ content by emission spectrometry after a KjeldahlRittenberg oxidation proceedure (Fiedler \& Proksch 1975). With the system in operation at our laboratories on optimum of $1.43 \mu$ mole of ammonium is required for each ${ }^{15} \mathrm{~N}$ determination. A reagent blank was prepared by measuring the dilution of ${ }^{15} \mathrm{~N}$-urea standards during sample preparation. A blank value of $1.44 \mu$ mole nitrogen for each sample was used to correct measured ${ }^{15} \mathrm{~N}$ enrichments. Corrected Kjeldahl nitrogen and total nitrogen values obtained from $\mathrm{CHN}$ analysis agreed closely.

A relative preference index (RPI) was calculated for each nutrient to compare utilization relative to availability. For example, for ammonium (McCarthy et al. 1977):
$\mathrm{RPI} \mathrm{NH}_{4}=$

$\frac{\varrho \mathrm{NH}_{4}}{\varrho \mathrm{NH}_{4}+\varrho \mathrm{NO}_{3}+\varrho \text { urea }} / \frac{\left[\mathrm{NH}_{4}\right]}{\left[\mathrm{NH}_{4}\right]+\left[\mathrm{NO}_{3}\right]+[\text { urea }]}$

where $\varrho \mathrm{NH}_{4}$, $\varrho \mathrm{NO}_{3}$ and $\varrho$ urea $=$ absolute uptake rates for each nutrient; $\left[\mathrm{NH}_{4}\right],\left[\mathrm{NO}_{3}\right]$ and [urea] $=$ their ambient concentrations.

Particulate nitrogen doubling times were calculated from the combined specific uptake rates $\left(\mathrm{h}^{-1}\right)$ assuming urea was taken up only in the light $(12 \mathrm{~h})$ and that dark ammonium and nitrate uptake were 25 and $10 \%$ of the light rate, respectively (Dugdale \& Goering 1967, unpubl. own results).

\section{RESULTS}

\section{Physical and chemical characteristics}

The stations have been separated into 3 regions depending on their physical and chemical characteristics:

(1) Shallow inshore (Stations 1, 12 and 13). Stations 1 and 12 are located at 2 active upwelling sites off the Cape Peninsula and off Hondeklip Bay (Nelson \& Hutchings 1983). These stations were typically well mixed with cold, nitrate-rich water at the surface (Table 1). Station 13, located near the mouth of the Olifants River, is included in this group on the basis of temperature and water depth.

(2) Oceanic offshore (Stations 2, 5 and 6). All these stations were characterised by warm, low nitrate, high salinity surface water (Table 1).

Table 1. Environmental data for the stations sampled showing nitrogenous nutrient concentrations, station depth, surface water temperature and salinity

\begin{tabular}{|c|c|c|c|c|c|c|}
\hline \multirow[t]{3}{*}{ Station } & \multicolumn{3}{|c|}{ Substrate } & \multirow{3}{*}{$\begin{array}{l}\text { Station depth } \\
\text { (m) }\end{array}$} & \multirow{3}{*}{$\begin{array}{l}\text { Temp } \\
\left({ }^{\circ} \mathrm{C}\right)\end{array}$} & \multirow{3}{*}{$\begin{array}{c}\text { Salinity } \\
(\%)\end{array}$} \\
\hline & Ammonium & Nitrate & Urea & & & \\
\hline & \multicolumn{3}{|c|}{ (mg-at $\left.\mathrm{N} \mathrm{m}^{-3}\right)$} & & & \\
\hline \multicolumn{7}{|l|}{ Inshore } \\
\hline 1 & 0.75 & 20.38 & 3.13 & ++ & 10.08 & 34.81 \\
\hline 12 & 0.40 & 24.35 & 0.32 & 29 & 10.22 & 34.88 \\
\hline 13 & 0.06 & 7.91 & 0.22 & 37 & 11.50 & 34.90 \\
\hline \multicolumn{7}{|l|}{ Shelf } \\
\hline 8 & 0.11 & 1.90 & 0.21 & 144 & 16.57 & 34.98 \\
\hline 9 & 0.22 & 1.05 & 0.59 & 135 & 15.31 & 34.94 \\
\hline 10 & 0.11 & 0.89 & 0.46 & 127 & 16.32 & 34.92 \\
\hline 11 & 0.24 & 1.45 & 0.71 & 120 & 13.28 & 34.92 \\
\hline 15 & 0.92 & 6.84 & 0 & 135 & 12.70 & 34.90 \\
\hline \multicolumn{7}{|l|}{ Oceanic } \\
\hline 2 & 0.56 & 0.92 & 0.83 & 1045 & 20.68 & 35.23 \\
\hline 5 & 0.44 & 0.08 & 0 & 1050 & 18.73 & 35.22 \\
\hline 6 & 0.32 & 0.02 & 0.34 & 1030 & 18.95 & 35.29 \\
\hline
\end{tabular}


Table 2. Abundances of the numerically important diatom and dinoflagellate species. Nanoflagellate $(<10 \mu \mathrm{m})$ counts include both heterotrophic and autotrophic forms. Bacterial carbon and tintinnid counts are also shown

\begin{tabular}{|c|c|c|c|c|c|c|c|c|c|c|c|}
\hline & \multicolumn{3}{|c|}{ Inshore } & \multicolumn{5}{|c|}{ Shelf } & \multicolumn{3}{|c|}{ Oceanic } \\
\hline & 1 & 12 & 13 & 8 & 9 & 10 & 11 & 15 & 2 & 5 & 6 \\
\hline \multicolumn{12}{|l|}{ Diatoms $\left(\times 10^{6} \mathrm{~m}^{-3}\right)$} \\
\hline Nitzschia delicatissima & 0.85 & 1.10 & 15.90 & 16.40 & 33.50 & 3.20 & 3.89 & 8.90 & 11.12 & 1.59 & \\
\hline N. seriata & 0.03 & & & 0.10 & & & & 121.20 & 0.25 & 0.11 & 0.05 \\
\hline Chaetoceros affinis & & 3.80 & 4.60 & & & & 559.40 & 7.30 & 0.25 & & \\
\hline C. compressus & & 2.50 & & & & 6.94 & 3419.30 & 17.80 & & 0.23 & \\
\hline C. sp. (small) & & & & & & 21.60 & & & & & \\
\hline Thallasiosira sp. & 0.03 & 27.90 & 3.20 & & & & 3.80 & & & & \\
\hline Skeletonema costatum & 0.72 & & & & & & & 8.60 & & & \\
\hline Leptocylindricus danicus & & & 30.20 & & & & & 3.20 & & & \\
\hline Asterionella sp. & 0.06 & & & 2.00 & 0.10 & & & 614.30 & & & \\
\hline Rhizosolenia alata & & & & & & & & & 0.32 & & \\
\hline R. setigera & & & & & & & & & 0.25 & 0.14 & \\
\hline R. delicatula & & & & & & & & & & & 6.47 \\
\hline Other diatom species & & 0.80 & 2.70 & & 0.70 & 0.50 & 0.80 & 1.40 & 0.41 & & 0.08 \\
\hline $\begin{array}{l}\text { Protoperidium spp. } \\
\text { Prom }\end{array}$ & & 0.20 & 6.50 & 0.20 & 0.10 & 0.80 & 6.20 & & & & 0.99 \\
\hline Gymnodinium spp. & & & & & & & & & 0.09 & & \\
\hline G. sp. (colourless) & 0.12 & & 1.90 & & & 18.90 & & & 0.65 & 0.40 & 0.90 \\
\hline Ceratium spp. & & & & 0.10 & & & & & 0.09 & 0.11 & 0.12 \\
\hline Gonyaulax digitalis & & 3.00 & & & & & & & & & \\
\hline Prorocentrum mucum & & & & & 0.10 & & & & & & \\
\hline Scripsiella sp. & & & 57.00 & & & & & 0.05 & & & \\
\hline Other dinoflagellate species & & 0.09 & 5.10 & 0.20 & & & 2.70 & 11.20 & & 0.13 & \\
\hline Nanoflagellates $\left(\times 10^{8} \mathrm{~m}^{-3}\right)$ & 2.66 & 11.72 & 38.95 & 3.13 & 7.71 & 0.24 & 31.51 & 33.20 & 1.36 & 1.36 & 5.46 \\
\hline Tintinnids $\left(\times 10^{6} \mathrm{~m}^{-3}\right)$ & 0.72 & & 63.70 & 2.02 & 3.16 & 1.20 & 11.30 & 1.70 & 0.45 & & 0.26 \\
\hline Bacteria ( $\mathrm{mg} \mathrm{C} \mathrm{m}-3$ ) & 9.34 & 13.29 & 41.55 & 52.64 & 78.80 & 31.25 & 61.43 & 58.82 & 12.21 & 17.89 & 24.72 \\
\hline
\end{tabular}

(3) Continental shelf (Stations 8, 9, 10, 11 and 15). These stations were intermediate in temperature and salinity and located between the 100 and $200 \mathrm{~m}$ depth contour.

\section{Phytoplankton and bacterial abundances}

Phytoplankton counts and bacterial carbon are shown in Table 2. Both diatom numbers and bacterial carbon were higher in coastal than in offshore waters. Similarly, the highest nanoflagellate counts (including both autotrophic and heterotrophic forms) were recorded in the inshore and shelf waters. The $<10 \mu \mathrm{m}$ size class was made up largely of these nanoflagellates.

\section{Particulate matter}

A summary of the various biomass parameters is given in Table 3 . The oceanic stations were characteristically low in chlorophyll a (chll a) and particulate organic matter (POM). Highest chll $a$ and POM values were recorded over the continental shelf. At all but Station 11 more than $50 \%$ of the POM was $<10 \mu \mathrm{m}$. A significant fraction ( 11 to $100 \%$ ) of the chll a was also recovered in this nanoplankton size class. At inshore Station 1 and oceanic Station 5 some 40 to $50 \%$ of the chll a was $<1 \mu \mathrm{m}$. There was a good correlation between particulate nitrogen and chll a concentrations for the different size classes (Fig. 2). The slope of the regression for the $<212 \mu \mathrm{m}$ size class $(\mathrm{b}=1.16$ ) being lower than the $<10 \mu \mathrm{m}(\mathrm{b}=1.64)$ and $<1 \mu \mathrm{m}(\mathrm{b}=$ 1.73) size classes indicates the intact community is chll a enriched compared to the smaller size fractions.

\section{Nitrogen assimilation rates}

Ammonium concentrations were monitored routinely before and after each uptake experiment. Initial concentrations for a particular sample were generally higher for the $<212 \mu \mathrm{m}$ size class than either the $<10 \mu \mathrm{m}$ or $<1 \mu \mathrm{m}$ size class suggesting stimulation of microzooplankton excretion after passing through the $212 \mu \mathrm{m}$ screen and confinement in the incubation bottle. Ammonium concentration changes during the incubations indicate that the surface water picoplankton are net mineralisers while the intact community $(<212 \mu \mathrm{m})$ was generally ammonium consuming (Fig. 3). 
Table 3. Concentrations of chlorophyll a (chll a), particulate organic nitrogen and carbon (PON and POC), and carbon/nitrogen ratios $(\mathrm{C} / \mathrm{N})$ for the 3 size fractions

\begin{tabular}{|c|c|c|c|c|c|c|c|c|c|c|c|c|}
\hline \multirow{3}{*}{ Insho } & \multirow{2}{*}{\multicolumn{3}{|c|}{$\begin{array}{c}\text { Chll } a \\
<212 \mu \mathrm{m}<10 \mu \mathrm{m}<1 \mu \mathrm{m} \\
\left(\mathrm{mg} \mathrm{m}^{-3}\right) \quad(\%)\end{array}$}} & \multicolumn{3}{|c|}{ PON } & \multicolumn{3}{|c|}{ POC } & \multicolumn{3}{|c|}{$\mathrm{C} / \mathrm{N}$} \\
\hline & & & & \multirow{3}{*}{$\begin{array}{c}\begin{array}{c}<212 \mu \mathrm{m} \\
\left(\mathrm{mmole} \mathrm{N} \mathrm{m}^{-3}\right)\end{array} \\
1.45\end{array}$} & \multicolumn{2}{|c|}{$\underset{(\%)}{<10 \mu \mathrm{m}<1 \mu \mathrm{m}}$} & \multirow{3}{*}{$\begin{array}{c}\underset{\left(\mathrm{mmole} \mathrm{C} \mathrm{m}^{-3}\right)}{12.25} \\
12\end{array}$} & \multicolumn{2}{|c|}{$\underset{(\%)}{<10 \mu \mathrm{m}<1 \mu \mathrm{m}}$} & \multicolumn{3}{|c|}{$<212 \mu \mathrm{m}<10 \mu \mathrm{m}<1 \mu \mathrm{m}$} \\
\hline & & & & & & & & & & & & \\
\hline 1 & 0.45 & 89 & 49 & & 53 & 24 & & 53 & 23 & 7.00 & 7.09 & 6.80 \\
\hline 12 & 1.47 & 11 & 8 & 2.93 & 63 & 17 & 19.75 & 69 & 25 & 5.78 & 6.31 & 8.36 \\
\hline 13 & 1.50 & 99 & 21 & 3.36 & 98 & 25 & 22.5 & 90 & 24 & 5.28 & 5.75 & 5.65 \\
\hline \multicolumn{13}{|c|}{ Shelf } \\
\hline 8 & 2.14 & 88 & 27 & 4.36 & 90 & 34 & 27.75 & 88 & 29 & 5.34 & 5.45 & 4.57 \\
\hline 9 & 5.56 & - & - & 6.79 & - & - & 57.50 & - & - & 7.26 & - & - \\
\hline 10 & 1.45 & - & - & 5.14 & - & - & 42.83 & - & - & 7.13 & - & - \\
\hline 11 & 7.88 & 26 & 9 & 8.93 & 38 & 17 & 62.08 & 37 & 18 & 5.96 & 5.87 & 6.52 \\
\hline 15 & 7.08 & 13 & 2 & 8.00 & 59 & 12 & 51.08 & 56 & 11 & 5.47 & 5.24 & 5.07 \\
\hline \multicolumn{13}{|c|}{ Oceanic } \\
\hline 2 & 0.57 & 13 & 5 & 0.93 & 54 & 30 & 6.75 & 61 & 41 & 6.23 & 7.14 & 8.38 \\
\hline 5 & 0.18 & 70 & 42 & 0.96 & 78 & 41 & 6.67 & 89 & 48 & 5.93 & 6.81 & 7.00 \\
\hline 6 & 0.33 & 30 & 8 & 1.42 & 75 & 33 & 11.08 & 69 & 26 & 5.65 & 5.13 & 5.23 \\
\hline
\end{tabular}

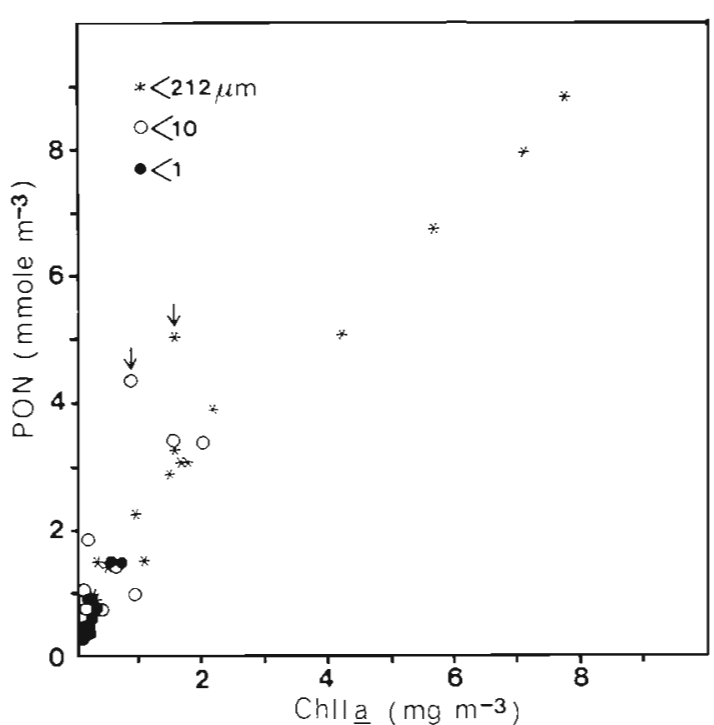

Fig. 2. Relationship between particulate organic nitrogen (PON) and chlorophyll a for the 3 size fractions. Regression equations were: $<1 \mu \mathrm{m}, \mathrm{PON}=0.301+1.734 \mathrm{chll}$ a $(\mathrm{r}=$ $0.90) ;<10 \mu \mathrm{m}$, PON $=0.651+1.643$ chll $a(\mathrm{r}=0.93)$; $<212 \mu \mathrm{m}$, PON $=0.995+1.164$ chll $a(\mathrm{r}=0.99)$. Points marked with arrows were excluded from regression analyses

A relative preference index (RPI) for each nutrient was calculated from the uptake rates for the 3 size fractions (Fig. 4). No relationship between size class and RPI was apparent in these data. The RPI's for ammonium were, with one exception, always in excess of unity, indicating a marked preference for this nutrient for all size fractions. Nitrate on the other hand was discriminated against at most stations, as indicated by the RPI's of less than unity. The RPI for urea was variable and as with ammonium tended to be positively related to the total nitrogenous nutrient

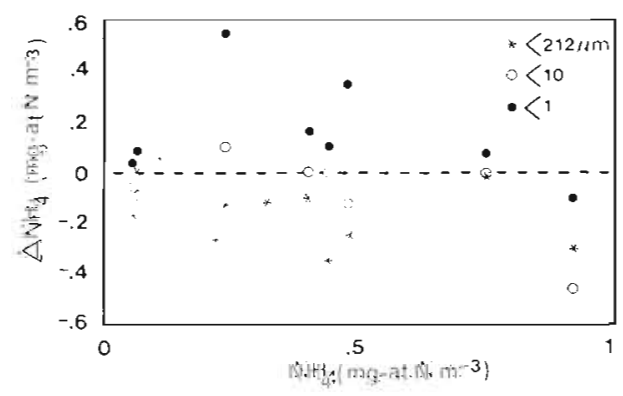

Fig. 3. Measured changes in ammonium concentrations $\left(\Delta \mathrm{NH}_{4}\right)$ over the time course of incubations (normalized to $4 \mathrm{~h}$ ) for the 3 size classes
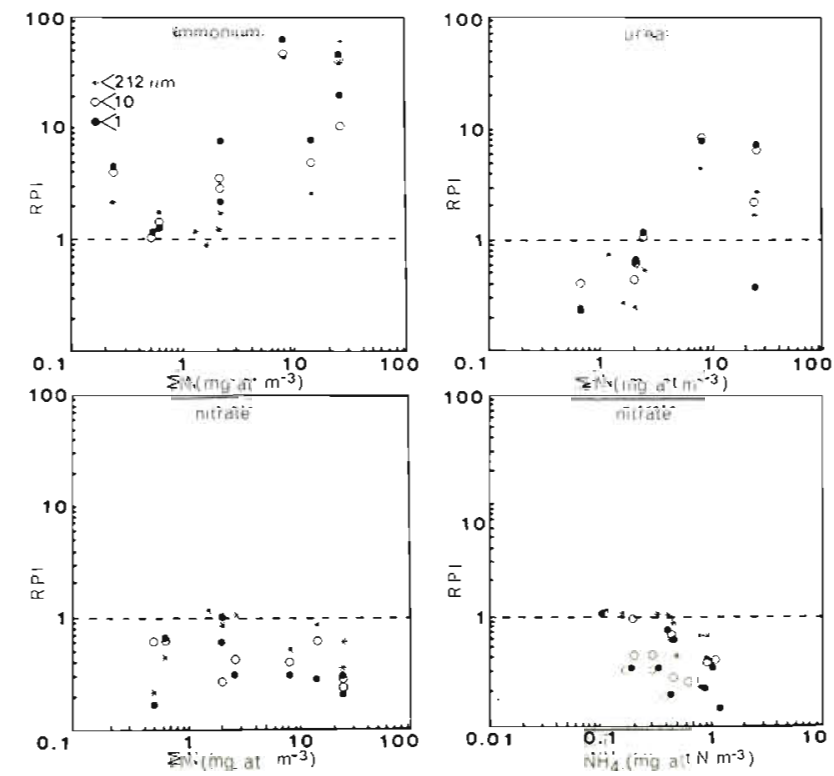

Fig. 4. Relative preference indices for ammonium, nitrate and urea (RPI's) as a function of the total nitrogenous nutrient concentration $(\Sigma N)$. Nitrate RPI's are also plotted against ammonium concentration 
concentration (Fig, 4). Nitrate RPI's, though independent of total dissolved nitrogen concentration, tended towards unity and above with diminishing ammonium concentrations (Fig. 4).

Ammonium accounted for most of the nitrogen assimilated for all 3 size fractions at the oceanic stations (Fig. 5). The proportion of ammonium assimilated

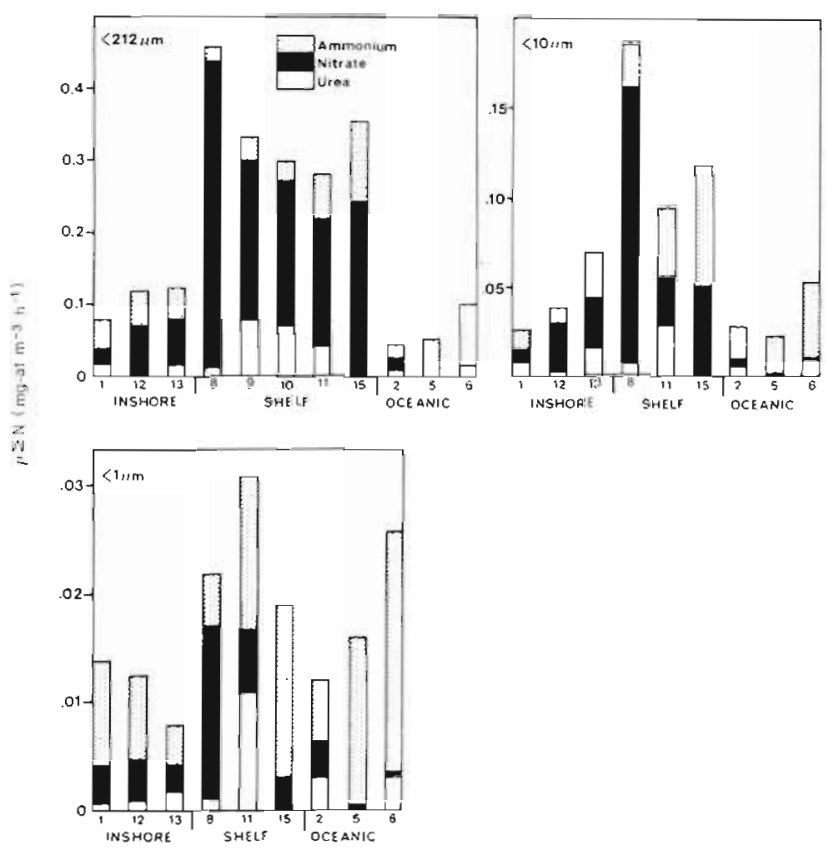

Fig. 5. Uptake rates for ammonium, nitrate and urea ( $\mathrm{Q} \Sigma N)$ for the 3 size classes in inshore, shelf and oceanic regions

increased when the larger size fractions were screened out at the shelf and inshore stations. The result being that, in all stations except Station 8, ammonium supplied the most nitrogen for growth of the picoplankton. Urea assimilation was variable but important at some stations especially for the picoplankton and nanoplankton. The proportion of total nitrogen assimilated as nitrate was directly related to increasing size for each of the shelf and inshore stations (Fig. 5).

Table 4 shows that nitrate formed the major portion of the nitrogen taken up by the intact community at the shelf and inshore stations. Ammonium and urea were

Table 4. Mean proportion of the total nitrogen assimilated as either ammonium, nitrate or urea for the intact phytoplankton community $(<212 \mu \mathrm{m})$

\begin{tabular}{|lccc|}
\hline Substrate & Inshore & $\begin{array}{c}\text { Region } \\
\text { Shelf } \\
(\%)\end{array}$ & Oceanic \\
\hline Nitrate & 48.0 & 71.2 & 13.3 \\
Ammonium & 38.5 & 15.1 & 73.7 \\
Urea & 13.5 & 13.7 & 13.1 \\
\hline
\end{tabular}

quantitatively the most important for phytoplankton nutrition at the oceanic stations. The picoplankton and nanoplankton size classes generally had longer particulate nitrogen doubling times than the whole community (Fig. 6). Mean doubling times for the intact

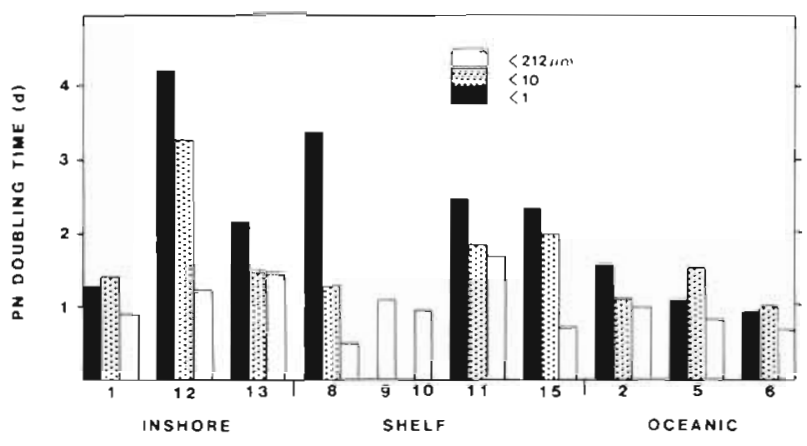

Fig. 6. Particulate nitrogen doubling times for the 3 size classes in inshore, shelf and oceanic regions

community were similar for the oceanic, shelf and inshore regions being $0.83 \mathrm{~d}, 1.00 \mathrm{~d}$ and $1.19 \mathrm{~d}$, respectively, Mean doubling times for the $<1 \mu \mathrm{m}$ size class were shorter in the oceanic environment $(1.19 \mathrm{~d}) \mathrm{com}$ pared to the shelf ( $2.76 \mathrm{~d}$ ) and inshore (2.75 d) waters. This trend was less obvious for the $<10 \mu \mathrm{m}$ fraction.

As one would expect from the doubling times, the picoplankton were relatively more active in nitrogen assimilation at the oceanic stations than coastal stations (Table 5). The contribution of the 1 to $10 \mu \mathrm{m}$ size

Table 5. Mean proportion of the total nitrogen assimilated by the picoplankton $(<1 \mu \mathrm{m})$, nanoplankton $(<10 \mu \mathrm{m})$, and the netplankton (10 to $212 \mu \mathrm{m}$ ) in inshore, shelf and oceanic regions

\begin{tabular}{|lrrrr|}
\hline Size class & & Inshore & $\begin{array}{c}\text { Region } \\
\text { Shelf } \\
(\%)\end{array}$ & Oceanic \\
\hline Picoplankton & $(<1 \mu \mathrm{m})$ & 11.1 & 7.1 & 26.9 \\
Nanoplankton & $(1-10 \mu \mathrm{m})$ & 29.6 & 28.8 & 24.5 \\
Netplankton & $(10 \sim 10 \mu \mathrm{m})$ & 40.7 & 35.8 & 51.4 \\
\cline { 1 - 3 } & & &
\end{tabular}

class (i.e. picoplankton exclusive) to total nitrogen assimilation was similar for the 3 regions.

The effect of substrate concentration on uptake rate was determined at three oceanic stations. The halfsaturation constants $\left(k_{m}\right)$ and maximum uptake velocities $\left(V_{\max }\right)$ are shown in Table 6 . The results indicate that ammonium is the most efficiently assimilated nitrogen resource at both low and high ambient concentrations. 
Table 6 . Kinetic parameters for ammonium, nitrate and urea uptake for the intact phytoplankton community at 3 oceanic stations. Michaelis-Menten parameters, $K_{m}$ (half-saturation constant) and $V_{\max }$ (maximal uptake velocity) were estimated from Hanes linear transformation

\begin{tabular}{|c|c|c|c|c|c|}
\hline Station & Substrate & $\begin{array}{l}\text { Correlation } \\
\text { coefficient }\end{array}$ & $\begin{array}{c}\mathrm{K}_{\mathrm{m}} \\
\left(\mathrm{mg} \text {-at } \mathrm{N} \mathrm{m}^{-3}\right)\end{array}$ & $\begin{array}{l}V_{\max } \\
\left(h^{-1}\right)\end{array}$ & $\mathrm{V}_{\max } / \mathrm{K}_{\mathrm{m}}$ \\
\hline 5 & Ammonium & 0.99 & 0.10 & 0.0098 & 0.0980 \\
\hline 7 & Urea & 0.99 & 0.17 & 0.0041 & 0.0241 \\
\hline 6 & Nitrate & 0.98 & 0.93 & 0.0082 & 0.0088 \\
\hline
\end{tabular}

\section{DISCUSSION}

\section{Biomass}

The proportion of chll a recovered in the surface water picoplankton fraction ( 2 to $50 \%$ of total chll a) is lower than the 25 to $90 \%$ depth integrated estimate of Li et al. (1983) for the eastern tropical Pacific Ocean. The higher picoplankton chll a estimates in the latter study probably indicates the greater importance of picoplankton as primary producers in tropical than temperate regions. In tropical waters picoplankton can account for 20 to $80 \%$ of the total inorganic carbon fixation (Li et al. 1983, Platt et al. 1983) while in the Celtic Sea they contribute 20 to $30 \%$ of the total primary production (Joint \& Pomroy 1983). Li et al. (1983) found that the picoplankton contribute a greater proportion to photosynthesis near the bottom of the euphotic zone in tropical waters than near the surface; this was not the case in the Celtic Sea study (Joint \& Pomroy 1983).

The large amount of chll $a$ in the $<10 \mu \mathrm{m}$ and $<1 \mu \mathrm{m}$ size classes at Station 1 indicate that newly upwelled water can be seeded by very small photoautotrophic cells, presumably mainly flagellates. Olivieri (1983) has shown that the mean cell size of 2 of the dominant diatom species increases as upwelled water matures in this upwelling area. This situation contrasts with Hondeklip Bay (Station 12) where newly upwelled water was dominated by larger diatom species, notably Thallassiosira sp.

\section{Total nitrogen assimilation}

One trend that did emerge from the uptake data and was not evident in the biomass data, was that the picoplankton and nanoplankton (inclusive of the picoplankton) were relatively more active nitrogen assimilators at the oceanic stations than over the shelf or inshore (Table 5). This finding is in line with the generalizations of Malone (1980) regarding the importance of netplankton and nanoplankton photosynthesis in such areas. The relatively long doubling times for the $<1 \mu \mathrm{m}$ and $<10 \mu \mathrm{m}$ size classes compared to the whole community at all stations is in agreement with the results of Furnas (1983) for particulate nitrogen doubling times in the $<10 \mu \mathrm{m}$ fraction. Direct measurements of mean microflagellate and non-motile ultraplankton biomass changes in diffusion chambers confirm that they turn over at a slower rate than the community as a whole (Furnas 1982). These findings appear to be at variance with the general trend of an increase in half-saturation constant for nitrogen uptake with an increase in cell size (Eppley et al. 1969). However, one might only expect such a relationship between cell size and nitrogen uptake in a low nutrient environmental, with concentrations at or below the $K_{m}$ values. Under nutrient saturated conditions large cells might grow more rapidly than small cells assuming they have a faster maximum growth rate (Parsons \& Takahashi 1973). On a less speculative note, it does appear from the regressions in Fig. 2 that the intact community $(<212 \mu \mathrm{m})$ is chll a enriched compared to the $<10 \mu \mathrm{m}$ and $<1 \mu \mathrm{m}$ fractions. In demonstrating the importance of netplankton nitrogen assimilation, these findings might explain the shorter doubling times of the whole community.

\section{Assimilation of individual nitrogen sources}

The combined data for the relative preference indices (RPI's) for the 3 nutrients (Fig. 4) is in good agreement with previous' studies (McCarthy et al. 1977. Glibert et al. 1982a) with ammonium generally the preferred substrate and nitrate usually rejected. Nitrate may be preferred under conditions of low $(<1 \mu \mathrm{M}$ ) ammonium concentration (Furnas 1983). A negative relationship between ammonium concentration and nitrate RPI was evident in the present study though nitrate was not taken up preferentially even at ammonium concentrations approaching $0.1 \mu \mathrm{M}$. (Fig. 4). Michaelis-Menten kinetics calculated for oceanic waters reveal that the efficiency of nitrogen uptake, measured as $\mathrm{V}_{\max } / \mathrm{K}_{\mathrm{m}}$ (Healey 1980) follows the pattern of RPI's: ammonium > urea > nitrate.

Relative preference indices provide a useful phy- 
siological measure but are not necessarily indicative of the routing of nitrogen into a cell on a quantitative basis. Ammonium and urea were generally quantitatively the more important nitrogen resource for the nutrition of the picoplankton and nanoplankton. Glibert et al. (1982a) similarly demonstrated that ammonium uptake was almost exclusively limited to the $<10 \mu \mathrm{m}$ size class. Over the shelf and inshore areas nitrate uptake by netplankton dominated, with Nitzschia and Chaetoceros the important genera. Since these were the productive regions, the overall result was that nitrogen productivity for the intact community increased with the proportion of nitrate assimilated (Fig. 7). A similar relationship has been demonstrated

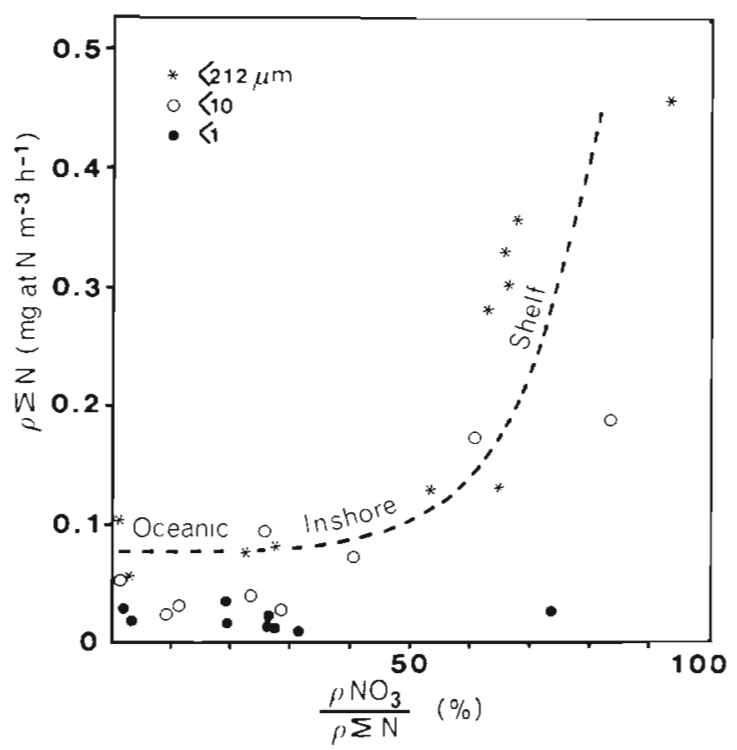

Fig. 7. Proportion of nitrate uptake ('new' production) as a

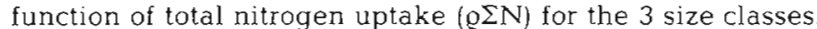
Curve fitted by eye for the $<212 \mu$ m fraction

for the depth-integrated proportion of nitrate assimilation versus primary production (Eppley et al. 1979). This relationship quantifies the importance of nitrate supply (advection or diffusion) to the primary production of an area not influenced by terrestrial runoff or benthic input of ammonium. The high rate of primary production characteristic of upwelling regions is apparently achieved only when the nitrate ration ('new' production) is in excess of $50 \%$ of the total nitrogen assimilated (Eppley et al. 1979, Yoder et al. 1983). This trend is progressively dampened with the exclusion of the netplankton and nanoplankton through differential screening (Fig. 7) and again illustrates the importance of the reduced nitrogen sources, ammonium and urea, to the nutrition of the picoplankton and the nanoplankton.

In a steady-state environment the advective and diffusive flux of nitrate should balance the loss or sinking rate i.e. 'new'/total production provides an index of the input to the aphotic water column and sediments (Eppley \& Peterson 1979, Eppley 1981). Harrison et al. (1983) have demonstrated a good agreement between sedimentation rates calculated in this manner and from sediment trap measurements in the Middle Atlantic Bight shelf. The mean ratio of 'new'/total production of $71 \%$ measured at the shelf in this study is in close agreement with the depth-integrated value of $67 \%$ for the Middle Atlantic Bight (Harrison et al. 1983). The southern Benguela shelf region can be treated as a steady-state flow system, with an inshore flow of nutrient rich water into the euphotic layer due to upwelling and a flow of nutrient impoverished water out of the layer due to sinking down the thermocline and northward drift (Andrews \& Hutchings 1980). The situation is, however, complicated by the intermittent nature of upwelling and patchy plankton distribution especially in the Cape Peninsula system (Hutchings 1981, Shannon et al. 1983).

The open ocean is probably reasonably close to a steady-state over suitably long temporal and spatial scales (Goldman et al. 1979). Thus the small ratio of 'new'/total production at the oceanic stations indicates little loss of primary production from the surface waters (ca $13 \%$ ) with most production being supported by regenerated nitrogen. This estimate of the flux of primary production from the euphotic zone is in good agreement with the values reported by Eppley \& Peterson (1979) for other offshore oceanic regions. Eppley (1981) suggests that the ratio of 'regenerated'/ new' production provides a measure fo the number of times nitrogen cycles before being exported from the upper water column. Experimental values for the southern Benguela system of $<1$ for coastal waters and $>>1$ for oceanic stations (Fig. 8) agree well with the generalizations of Eppley (1981).

The above discussion regarding the importance of 'new' production to the shelf and oceanic surface waters is biased because of the inherent error of not taking isotope dilution into account in measurements

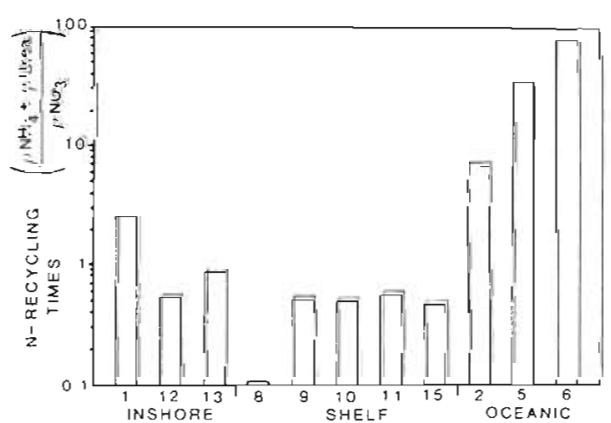

Fig. 8. Nitrogen recycling times in surface waters for inshore, shelf and oceanic regions; calculated from the ratio of 'regenerated' to 'new' production 
of ammonium uptake. Glibert et al. (1982b) have shown that under a variety of field conditions ammonium uptake is typically underestimated by a factor of ca 2 when a constant ${ }^{15} \mathrm{~N}$ enrichment is assumed. Using the same correction factor with the present data reduces 'new' production for the intact community to $65 \%$ over the shelf and $11 \%$ in oceanic waters. Accounting for ammonium isotope dilution in the $<1 \mu \mathrm{m}$ and $<10 \mu \mathrm{m}$ size fractions would streng then the claim for a dominant role of 'regenerated' nitrogen in the nutrition of picoplankton and nanoplankton.

It is most likely that urea is supplied to the euphotic zone through bacterial degradation and animal excretion (McCarthy 1980). The relative contribution of urea to nitrogen assimilation was characteristically highly variable (range 1 to $35 \%$ ) and was somewhat lower than found in other studies (McCarthy 1972, Kristiansen 1983). In a coastal lagoon off Long Island, urea on average provided $50 \%$ of the nitrogen utilized, possibly a result of assimilation by the large numbers of small ( 1 to $4 \mu \mathrm{m}$ ) chlorophyceae and cyanophyeae in this area (Kaufman et al. 1983). There was no clear correlation between $\varrho$ urea/total nitrogen assimilation and $<10 \mu \mathrm{m}$ flagellate or bacterial counts in the present study.

In conclusion, this study suggests that in the inshore and shelf waters influenced by upwelling, the picoplankton do not play as significant a role in nitrogen uptake as in the oceanic waters. The importance of this size class to nitrogen cycling in the surface waters both inshore and offshore is probably in ammonium regeneration (Harrison 1978, Glibert 1982, Harrison et al. 1983). In the oceanic environment the reduced nitrogen sources of ammonium and urea are quantitatively the most important for the nutrition of all size classes within the phytoplankton community.

This study supports the hypothesis that netplankton productivity is largely nitrate controlled, whereas nanoplankton productivity is regulated by regenerated nitrogen (Malone 1980, Glibert et al. 1982a). This generalization can be extended to include the picoplankton along with the nanoplankton. It should be remembered that the present study gives no indication of possible seasonal or shorter time-scale trends in the pattern of nitrogen assimilation which, in a pulsed system such as the southern Benguela, are likely to be appreciable. Expanding on these findings one would predict that moderate shifts in the strength and direction of the prevailing wind field over the upwelling season would result in measurable changes in the size structure of the phytoplankton community. The proportion of nanoplankton and picoplankton is likely to increase with a reduction in upwelling intensity and hence nitrate supply. Results of an upwelling monitoring cruise off the Cape Peninsula during March 1983, an anomalous warm-event year, indicated a predominance of small flagellates over diatoms (Hutchings et al. 1984) providing indirect support for this hypothesis. The smaller mean size of the primary producers under these conditions might necessitate additional intermediaries in the transfer of carbon and nitrogen from phytoplankton to zooplankton, with possible detrimental affects on the overall efficiency of the food chain leading to pelagic fish.

Acknowledgements. I am grateful to Professor J. G. Field and Dr. M. I. Lucas for criticism of the manuscript and to Professor O. A. M. Lewis for the use of his ${ }^{15} \mathrm{~N}$ analyser. Mr. I. Humphrey and Ms. S. Painting provided the bacterial counts and Ms. C. M. Weekley the phytoplankton counts. I would like to thank Mr. G. Nelson for his cooperation as chief scientist and Ms. H. Wessels for her assistance during the Dec 1983 cruise on the R.V. 'Africana'. Permission to participate in this cruise was obtained from the Dept. of Sea Fisheries. This study was funded by the Phytoplankton Studies Project, Benguela Ecology Programme, SANCOR.

\section{LITERATURE CITED}

Andrews, W. R. H., Hutchings, L. (1980). Upwelling in the southern Benguela current region. Prog. Oceanogr. 9: $1-81$

Doetsch, R. N., Cook, T. M. (1973). Introduction to bacteria and their ecobiology. University Park Press, Baltimore

Dugdale, R. C., Goering, J. J. (1967). Uptake of new and regenerated forms of nitrogen in primary productivity. Limnol. Oceanogr. 12: 196-206

Eppley, R. W. (1981). Autotrophic production of particulate matter. In: Longhurst, A. R. (ed.) Analysis of marine ecosystems. Academic Press, London, p. 343-361

Eppley, R. W., Peterson, B. J. (1979). Particulate organic matter flux and planktonic new production in the deep ocean. Nature, Lond. 279: 210-215

Eppley, R. W., Renger, E. H., Harrison, W. G. (1979). Nitrate and phytoplankton production in southern California coastal waters. Limnol. Oceanogr. 24: 483-494

Eppley, R. W., Rogers, J. N., McCarthy, J. J. (1969). Halfsaturation constants for uptake of nitrate and ammonium by marine phytoplankton. Limnol. Oceanogr. 14: 912-920

Fiedler, R., Proksch, G. (1975). The determination of nitrogen15 by emission and mass spectrometry in biochemical analysis: a review. Analyt. Chim. Acta 78: 1-62

Furnas, M. J. (1982). Growth rate of summer nanoplankton $(<10 \mu \mathrm{m})$ populations in lower-Narragansett Bay, Rhode Island, USA. Mar. Biol. 70: 105-115

Furnas, M. J. (1983). Nitrogen dynamics in lower-Narragansett Bay, Rhode Island. I. Uptake by size-fractionated phytoplankton populations. J. Plankton Res. 5: 657-675

Gieskes, W. G. C., Kraay, G. W., Baars, M. A. (1979). Current ${ }^{14} \mathrm{C}$ methods for measuring primary production: gross underestimates in oceanic waters. Neth. J. Sea Res. 13: $58-78$

Glibert, P. M. (1982). Regional studies of daily, seasonal and size-fraction variability in ammonium remineralization. Mar. Biol. 70: 209-222

Glibert, P. M., Goldman, J. C., Carpenter, E. J. (1982a). Seasonal variations in the utilization of ammonium and 
nitrate by phytoplankton in Vineyard Sound, Massachusetts, USA. Mar. Biol. 70: 237-249

Glibert, P. M., Lipshultz, F., McCarthy, J. J., Altabet, M. M. (1982b). Isotope dilution models of uptake and remineralization of ammonium by marine phytoplankton. Limnol. Oceanogr. 27: 639-650

Goldman, J. C., McCarthy, J. J, Peavey, D. G. (1979). Growth rate influence on the chemical composition of phytoplankton in oceanic waters. Nature, Lond. 279: 210-215

Goldman, J. C., Taylor, C. D., Glibert, P. M. (1981). Nonlinear time course uptake of carbon and ammonium by marine phytoplankton. Mar. Ecol. Prog. Ser. 6: 137-148

Grasshoff, K. (1976). Methods of seawater analysis. Weinheim, Verlag Chemie

Harrison, W. G. (1978). Experimental measurements of nitrogen remineralization in coastal waters. Limnol. Oceanogr. 23: $684-694$

Harrison, W. G., Douglas, D., Falkowski, P., Rowe, O., Vidal, J. (1983). Summer nutrient dynamics of the Middle Atlantic Bight: nitrogen uptake and regeneration. J. Plankton Res. 5: 539-556

Healey, F. P. (1980). Slope of the Monod equation as an indicator of advantage in nutrient competition. Microb. Ecol. 5: 281-286

Herbland, A. (1976). In situ utilization of urea in the euphotic zone of the Tropical Atlantic. J. exp. mar. Biol. Ecol. 21: $269-277$

Hobbie, J. E., Daley, J. R., Jasper, S. (1977). Use of nuclepore filters for counting bacteria by fluorescence microscopy. Appl. Environ. Microbiol. 33: 1225-1228

Hutchings, L. (1981). The formation of plankton patches in the southern Benguela current. In: Richards, F. A. (ed.) Coastal upwelling. American Geophysical Union, Washington, D. C., p. $496-506$

Hutchings, L., Holden, C., Mitchell-Innes, B. (1984). Hydrobiological and biological shipboard monitoring of upwelling off the Cape Peninsula. S. Afr. J. Sci. 80: 83-89

Jeffrey, S. W., Humphrey, G. F. (1975). New spectrophotometric equations for determining chlorophylls $\mathrm{a}, \mathrm{b}, \mathrm{c}_{1}$ and $\mathrm{c}_{2}$ in higher plants, algae and natural phytoplankton. Biochem. Physiol. Pflanzen 167: 191-194

Johnson, P. W., Sieburth, J. McN. (1979). Chroococcoid cyanobacteria in the sea: a ubiquitous and diverse phototrophic biomass. Limnol. Oceanogr. 24: 928-935

Johnson, P. W., Sieburth, J. McN. (1982). In situ morphology and occurrence of eucaryotic phototrophs of bacterial size in the picoplankton of estuarine and oceanic waters. J. Phycol. 18: 318-327

Joint, I. R., Pomroy, A. J. (1983). Production of picoplankton and small nanoplankton in the Celtic Sea. Mar. Biol. 77 $19-27$

Kaufman, Z. G., Lively, J. S., Carpenter, E. J. (1983). Uptake of nitrogenous nutrients by phytoplankton in a barrier island estuary: Great South Bay, New York. Estuar. coast. Shelf Sci. 17: 483-493
Kristiansen, S. (1983). Urea as a nitrogen source for the phytoplankton in the Oslofjord. Mar. Biol. 74: 17-24

Laws, E. (1984). Isotope dilution models and the mystery of the vanishing ${ }^{15} \mathrm{~N}$. Limnol. Oceanogr. 29: 379-386

Li, W. K. W., Subba Rao, D. W., Harrison, W. G., Smith, J. C., Cullen, J. J., Irwin, B., Platt, T. (1983). Autotrophic picoplankton in the tropical ocean. Science 219: 292-295

Malone, T. C. (1980). Algal size. In Morris, I. (ed.) The Physiological Ecology of Phytoplankton. Blackwell Scientific Publications, London, p. 433-463

McCarthy, J. J. (1977). Nitrogenous nutrition of the plankton in the Chesapeake Bay. 1. Nutrient availability and phytoplankton preferences. Limnol. Oceanogr. 22: 996-1011

McCarthy, J. J. (1982). The uptake of urea by natural populations of marine phytoplankton. Limnol. Oceanogr. 17: 738-748

McCarthy, J. J., Taylor, W. R., Taft, J. L. (1977). Nitrogenous nutrition of the plankton in the Chesapeake Bay. 1. Nutrient availability and phytoplankton preferences. Limnol. Oceanogr. 22: 996-1011

Nelson, G., Hutchings, L. (1983). The Benguela upwelling area. Prog. Oceanogr. 12: 333-356

Nydahl, F. (1976). On the optimum conditions for the reduction of nitrate to nitrite by cadmium. Talantia 23 : 349-357

Olivieri, E. T. (1983). Colonization, adaptations and temporal changes in diversity and biomass of a phytoplankton community in upwelled water of the Cape Peninsula, South Africa, in December 1979. S. Afr. J. mar. Sci. 1: 77-109

Parsons, T. R., Takahashi, M. (1973). Environmental control of phytonplankton cell size. Limnol. Oceanogr. 18: 511-515

Platt, T., Subba Rao, D. V., Irwin, B. (1983). Photosynthesis of picoplankton in the oligotrophic ocean. Nature, Lond. 301: $702-704$

Savidge, G., Hutley, H. T. (1977). Rate of remineralization and assimilation by fractionated plankton populations in coastal waters. J. exp. mar. Biol. Ecol. 28: 1-6

Shannon, L. V., Mostert, S. A., Walters, N. M., Anderson, F. P. (1983). Chlorophyll concentrations in the southern Benguela current region as determined by satellite (Nimbus- 7 coastal zone colour scanner). J. Plankton Res. 5: 565-583

Sieburth, J. McN., Smetacek, V., Lentz, T. (1978). Pelagic ecosystem structure: heterotrophic compartments of the plankton and their relationship to plankton size fractions. Limnol. Oceanogr. 23: 1256-1263

Strickland, J. D. H., Parsons, T. R. (1972). A practical handbook of seawater analysis. Bull. Fish. Res. Bd Can. 167 $1-311$

Troitsky, A. S., Sorokin, Y. I. (1967). On the methods of calculation of bacterial biomass in water bodies. Trans. Biol. Inland Waters Acad. Sci. USSR. 19: 85-90

Yoder, J. A., Atkinson, L. P., Bishop, S. S., Hofmann, E. E., Lee, T. N. (1983). Effect of upwelling on phytoplankton productivity of the outer southeastern United States continental shelf. Continental Shelf Res. 1. 385-404 